\title{
CHARACTERIZATION OF T CELL RECEPTORS IN AFRICAN LUNGFISH (PROTOPTERUS DOLLOI) AND THEIR ROLE IN MUCOSAL IMMUNITY
}

\author{
Magadán, $S^{1}$, Tacchi $L^{1}$, Heimroth $\mathbf{R}^{1}$, Salinas $\mathbf{I}^{\mathbf{1}^{*}}$ \\ ${ }^{1}$ Center of Evolutionary and Theoretical Immunology, Department of Biology, University of New Mexico, \\ New Mexico, USA.
}

\begin{abstract}
Lungfish (Dipnoi) are the closest relatives to all living tetrapods. The immune system of this group of species is particularly interesting since it may provide insights about the changes in the immune system associated with the water-to-land transition of vertebrates. We recently reported all the immunoglobulin molecules expressed by two different African lungfish species, Protopterus dolloi and P. annectens. However, to date, no studies on T cell receptor (TCR) molecules have been conducted in lungfish. Using deep sequencing databases as well as a RACE approach, we have identified TCR $\alpha$, TCR $\beta$, TCR $\delta$ and TCR $\gamma$ sequences in P. dolloi. Amino acid sequence analysis and phylogenetic trees were performed and results support that Dipnoi are more closely related to tetrapods. V segment usage by each TCR gene in $P$. dolloi systemic versus mucosa-associated lymphoid tissue is presented. Constitutive expression studies in control lungfish indicate a low expression of TCR $\gamma$ in all tissues tested. In response to nasal infection with Edwardsiella ictaluri, increased expression of TCR $\alpha, \operatorname{TCR} \beta$ and TCR $\delta$ but not TCR $\gamma$ was detected in the pre-pyloric spleen and gut of $P$. dolloi. On the other hand, significant decreased expression in the same three genes was observed in the lung and post-pyloric spleen. Future studies will complete our current understanding of TCR evolution in vertebrates and may shed light to the unique features of the tetrapod T cell system.
\end{abstract}

\section{KEYWORDS}

TCR, Dipnoi, African lungfish, V segment, mucosal immunity

*Corresponding author. Tel.: +1 505-277-0039

E-mail address: isalinas@unm.edu 